\title{
複断面開水路における樹林の流水抵抗 に関する相当粗度係数 \\ EQUIVALENT MANNING ROUGHNESS COEFFICIENT IN AN OPEN CHANNEL OF COMPOUND CROSS SECTION WITH TREE VEGETATTION
}

\author{
米谷駿一 ${ }^{1} \cdot$ 魚谷拓矢 $^{1} \cdot$ 道奥康治 $^{2} \cdot$ 神田佳 $^{3} \cdot$ 入江良幸 $^{4} \cdot$ 柳田昂希 $^{4}$ \\ Shunichi KOMETANI, Takuya UOTANI, Kohji MICHIOKU, \\ Keiichi KANDA, Yoshiyuki IRIE and Kouki YANAGIDA \\ 1学生会員 学士（工） 神戸大学大学院工学研究科（†657-8501 神戸市灘区六甲台町1-1） \\ 2 フェロー会員 工博 神戸大学大学院工学研究科（同 上） \\ 3正会員 工博 明石工業高等専門学校（广674-8501 明石市魚住町西岡679-3） \\ 4明石工業高等専門学校（同 上）
}

\begin{abstract}
The high water level, HWL. for a design flood is the most important parameter in flood control and management. It is a critical issue how to determine Manning roughness coefficient in a vegetated reach, since channelized rivers tend to be densely vegetated in last decades. Although there are several sophisticated hydrodynamic models to analyze flows in vegetated channels, flow resistance due to vegetation is usually formulated in terms of a drag force coefficient which is not always a convenient parameter in flood control management. The HWL. is usually determined from a one dimensional nonuniform flow analysis in which Manning roughness coefficient is required in describing channel perimeter's roughness such as vegetation. In this study, an equivalent Manning roughness coefficient, $n_{\mathrm{v}}$, for a vegetated reach was theoretically estimated by using a two-dimensional two-layer (2D2L) flow model that was developed by the authors. The model's performance was already confirmed by laboratory and field experiments. A functional dependency of $n_{\mathrm{v}}$ on vegetation properties such as discharge, profiles of vegetation, stem diameter, tree height, etc. was investigated. It was found that $n_{\mathrm{v}}$ was kept constant independently of water depth or discharge after the vegetation being submerged.
\end{abstract}

Key Words : Manning roughness coefficient, vegetated channel, compound cross section

\section{1. 序論}

河川敷の樹林消長は土砂収支とともに河川に発生する 予測困難な自然現象であり，河川の維持・管理上の課題 となっている. 砂州の固定化した河川では樹林が過剰に 繁茂し，河川の機能障害をもたらしている．特に，砂磕 砂州で構成されていた中下流部における樹木繁茂は，疎 通機能の低下，流木生産，生態系のレジーム・シフトを もたらす要因となる.

河川法は治水・環境・利水機能の一体的な高度化を目 指しているが，第一に計画高水を安全に流下させるよう な河積の確保が河川整備の前提にある.しかし, 現実に は整備後に樹林化が進み，計画水準の疎通能力を維持す るために樹木伐採を継続しなければならないことが多い. 樹林化した河道で計画規模の洪水が発生した場合に水位
をHWL.以下に収めるためには，樹林の粗度効果を定量 化し縦断水面形を適切に評価する必要がある. 水理解析 のために様々なモデルが提案されているが，その多くで は樹木の高さ・幅に応じた流水阻害面積と水深平均流速 によってあらわされた抗力型の抵抗則が用いられている. しかし，計画高水の流量規模では，河川敷樹木の多くが 完全に冠水するため, 樹冠上の高速流と樹林内の低速流 からなる二層流構造が形成される。この場合，上下層間 の鉛直速度せん断にともなう質量・運動量交換が，高水 敷一低水路間の水平速度せん断と同様に, 流れの動力学 に支配的な役割を果たす。この場合には，多くのモデル でなされているように，樹木の抵抗力を水深平均流速に よって表すことは適切ではなく, 著者らは二層流構造を 考慮した二次元二層流（2D2L）モデルを開発した。 2D2Lモデルは捨石水制や捨石堰などの透過性構造物が 設置された開水路流 ${ }^{1)}$ ，実河川の洪水流 ${ }^{2 \sim 5)} の$ 再現に適用 


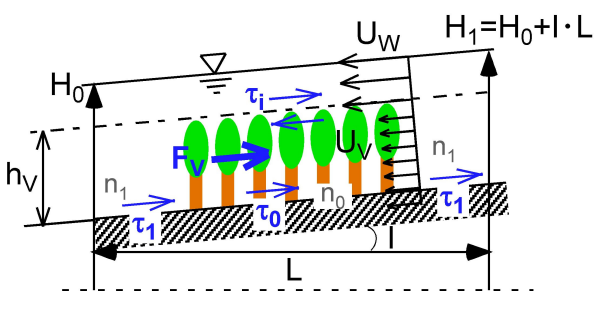

(a) 樹林化した開水路流の動力学

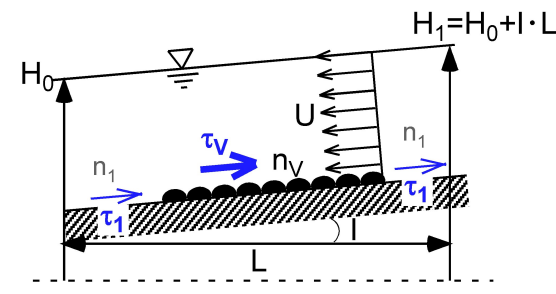

(b) 相当粗度係数 $n_{\mathrm{V}}$ によって樹木抵抗を 表現した開水路流の動力学

図-1 相当粗度係数 $n$ のの解析イメージ

されてきた。河道の詳細設計段階では，こうした二次 元・三次元流解析が有用であるが，治水計画では，樹林 を含む河道内の各種粗度要素をマニングの粗度係数で表 現し，計画高水流量に対する一次元不等流解析を実施す る．その際，安全側の原則に基づき，樹林による河積の 完全阻害や大き目の粗度係数を与えてHWL.を推定する 傾向にある. しかし，過小・過大の治水事業を避けるた めには，合理的・的確な粗度係数の評価が不可欠となる.

事例的な水理条件に限定されるが，本研究では樹林の 完全冠水状態における開水路流を2D2Lモデルにより解 析し，樹林部の相当粗度係数 $n_{\mathrm{v}}$ を推算する. これにより， 洪水痕跡など情報や実績がない区間でも，樹径・樹高・ 密生度などの樹林特性から $n_{\mathrm{v}}$ が水理学的に評価され，治 水管理のための水面形解析が可能となる. さらに， $n_{\mathrm{v}}$ の 解析解を検証し2D2Lモデルの妥当性を確認するために, 単純な樹木条件における水理模型実験も実施し，樹林抵 抗の説明変数としての $n_{\mathrm{v}}$ の供用性を明らかにする.

\section{2D2Lモデルによる相当粗度係数 $n_{V}$ の算出方法}

\section{(1) 相当粗度係数 $n$,の定義}

図-1(a)のように樹林が完全に水没した開水路流では, 樹冠上層が高速流（流速： $U_{\mathrm{W}}$ ）で，樹林層は低速流 (流速 $: U_{\mathrm{V}}$ ) である. 2D2Lモデル1) 5)では，樹冠上面に 沿って内部境界面が設定され，下層から上層への連行流 速 $W_{\mathrm{e}}$ を連続式から求める. 内部境界面での鉛直せん断力 て は次式で表される.

$$
\tau_{\mathrm{i}}=\rho W_{e}\left|U_{\mathrm{w}}-U_{\mathrm{V}}\right|
$$

単位水平面積あたりの樹木抵抗力 $F_{\mathrm{V}}$ は,

$$
F_{\mathrm{v}}=\frac{1}{2} \rho C_{\mathrm{D}} \lambda_{\text {veg }} U_{\mathrm{v}}^{2} h_{\mathrm{v}}
$$

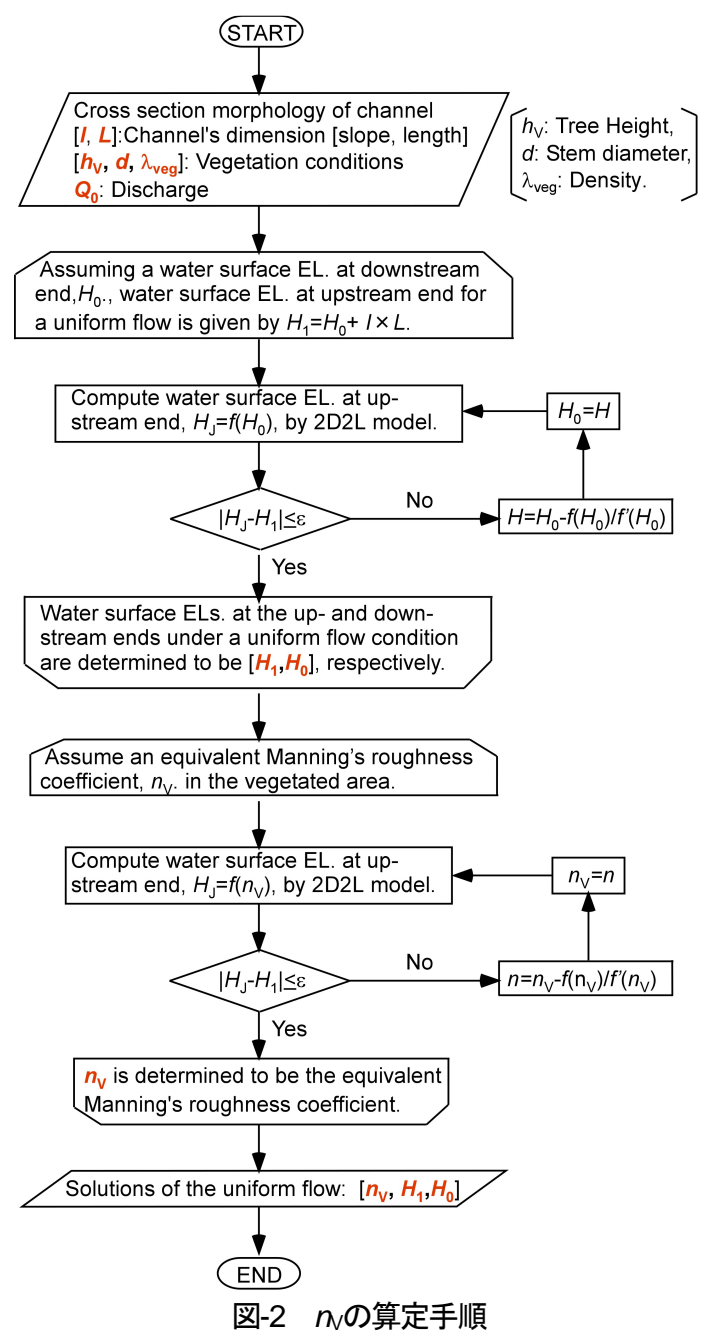

により与えられる. ここで， $\rho$ : 水の密度， $C_{\mathrm{D}}$ : 抗力係 数, $\lambda_{\mathrm{veg}}$ : 密生度, $h_{\mathrm{V}}$ : 樹木高さ，である．樹林床の壁面 せん断力 $\tau_{0}$ も林床の粗度係数 $n_{0}$ と樹林内の実流速 $U_{\mathrm{V}} / p(p$ : 樹林の間隙率) を用いて評価される.

図-1(a)の樹林を図-1(b)のような相当粗度に置換して, 図-1(a)の樹林帯部に介在する全ての力学系を，図-1(b)の 浅水流としての樹林帯が受け持つ局所的な壁面せん断力 $\tau_{\mathrm{V}}$ で次のように表現した場合に

$$
\tau_{\mathrm{v}}=\frac{\rho g n_{\mathrm{V}}^{2} U^{2}}{R^{1 / 3}}
$$

本研究では， $n_{\mathrm{v}}$ を「相当粗度係数」と称する.

\section{(2) 相当粗度係数n、の算定手順（図-2）}

本研究では， $n_{\mathrm{v}}$ を用いて樹林抵抗力を壁面摩擦力に換 算することを目的とする. $n_{\mathrm{v}}$ の定数パラメータとしての 可能性を検証するために，検討対象を単純な直線複断面 の開水路等流に限定するが，以下に示す $n_{\mathrm{v}}$ の算定手順は， 任意地形の河川でも同様である.

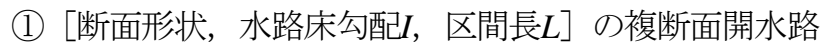
において樹木諸元 [樹高 $h_{\mathrm{V}}$, 樹径 $d_{\mathrm{V}}$, 樹林帯幅 $B_{\mathrm{v}}$, 樹木密 度 $N]$ を想定する.

(2)ある流量 $Q_{0}$ に対する等流状態は，下流端水位 $H_{0}$ に対し 


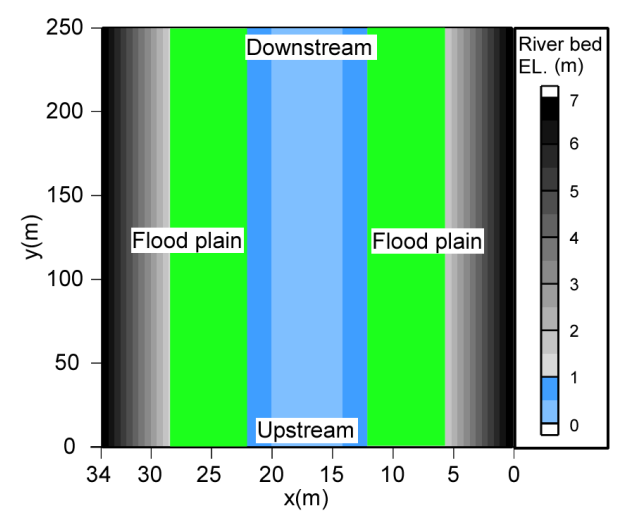

(a) 平面形状

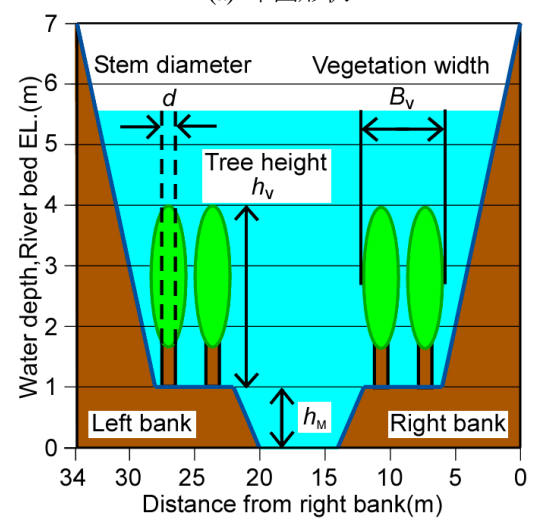

(b) 横断面形状

図-3＼cjkstart解析対象とする複断面開水路と諸元の定義

2D2Lモデルから得られる上流端水位 $H_{\mathrm{J}}$ が，等流の解 $H_{1}=H_{0}+I \cdot L$ に一致するまで, $H_{0}$ を繰り返し更新して得ら れる. 2D2Lモデルを介した $H_{\mathrm{J}}$ と $H_{0}$ との関数関係を

$$
H_{\mathrm{J}}=f\left(H_{0}\right)
$$

とおけば， $H_{0}$ の更新值 $H$ はNewton-Raphson法によって次 式のように与えられる.

$$
H=H_{0}-f\left(H_{0}\right) / f^{\prime}\left(H_{0}\right)
$$

(3)樹林帯部の相当粗度係数 $n_{\mathrm{v}}$ の解を求める. (2)で得られ

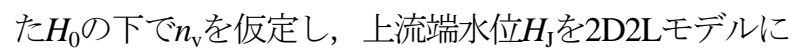
よって求める. その際, 樹林帯以外の部分はあらかじめ 決定した底面摩擦によるマニングの粗度係数(表-1)を用 いている. $H_{\mathrm{J}}$ が等流の解 $H_{1}=H_{0}+I \cdot L$ に一致するまで, $n_{\mathrm{v}}$ を繰り返し更新して $n_{\mathrm{v}}$ の収束解が得られる. 2D2Lモデ ルを介した $H_{\mathrm{J}}$ と $n_{\mathrm{v}}$ との関数関係を

$$
H_{\mathrm{J}}=f\left(n_{\mathrm{V}}\right)
$$

とおけば， $n_{\mathrm{v}}$ の更新值 $n$ はNewton-Raphson法により次式 で与えられる.

$$
n=n_{\mathrm{V}}-f\left(n_{\mathrm{v}}\right) / f^{\prime}\left(n_{\mathrm{V}}\right)
$$

(4)以上の手順で所定の河道・樹木諸元の下で流量 $Q_{0}$ に対 寸る等流状態の上下流端水位 $\left(H_{0}, H_{1}\right)$ と相当粗度係数 $n_{\mathrm{v}}$ の 解が得られる. また, 水位と河床位から等流水深 $h_{0}$ を求 めて, 「水位一流量」関係 $\left(h_{0}, Q_{0}\right)$ を得る. ここで，等流水

\begin{tabular}{|c|c|c|c|c|c|}
\hline CASE & $\begin{array}{l}\text { 樹径 } \\
d(\mathrm{~m})\end{array}$ & $\begin{array}{c}\text { 樹高 } \\
h_{\mathrm{V}}(\mathrm{m})\end{array}$ & $\begin{array}{c}\text { 樹木密度 } \\
N\left(\mathrm{~m}^{-2}\right)\end{array}$ & $\begin{array}{c}\text { 密生度 } \\
\lambda_{\text {veg }}\left(\mathrm{m}^{-1}\right)\end{array}$ & $\begin{array}{c}\text { 樹林帯幅 } \\
B_{\mathrm{V}}(\mathrm{m})\end{array}$ \\
\hline $1 \mathrm{a}$ & 0.04 & \multirow{3}{*}{3.0} & \multirow{9}{*}{0.1} & 0.004 & \multirow{3}{*}{6.0} \\
\hline $1 \mathrm{~b}$ & 0.08 & & & 0.008 & \\
\hline $1 \mathrm{c}$ & 0.12 & & & 0.012 & \\
\hline $2 \mathrm{a}$ & \multirow{3}{*}{0.08} & 2.0 & & \multirow{3}{*}{0.008} & \multirow{3}{*}{6.0} \\
\hline $2 b$ & & 3.0 & & & \\
\hline $2 \mathrm{c}$ & & 4.0 & & & \\
\hline $3 a$ & \multirow{3}{*}{0.12} & \multirow{3}{*}{3.0} & & \multirow{3}{*}{0.012} & 2.0 \\
\hline $3 b$ & & & & & 4.0 \\
\hline $3 \mathrm{c}$ & & & & & 6.0 \\
\hline $4 a$ & \multirow{5}{*}{0.1} & \multirow{5}{*}{3.0} & 0.01 & 0.001 & \multirow{5}{*}{6.0} \\
\hline $4 b$ & & & 0.03 & 0.003 & \\
\hline $4 c$ & & & 0.05 & 0.005 & \\
\hline $4 d$ & & & 0.07 & 0.007 & \\
\hline $4 \mathrm{e}$ & & & 0.09 & 0.009 & \\
\hline
\end{tabular}

表-1 水理 · 河道条件

\begin{tabular}{|c|c|c|}
\hline 流量 : $Q\left(\mathrm{~m}^{3} / \mathrm{s}\right)$ & \multicolumn{2}{|c|}{$50 \sim 400$} \\
\hline 河床勾配 : & \multicolumn{2}{|c|}{$1 / 800$} \\
\hline \multirow{2}{*}{$\begin{array}{c}\text { マニングの粗度係 } \\
\text { 数 }: n\left(\mathrm{~m}^{-1 / 3} \cdot \mathrm{s}\right)\end{array}$} & 低水路 & 0.028 \\
\cline { 2 - 3 } & 高水敷 & 0.055 \\
\cline { 2 - 3 } & 樹林床 & 0.031 \\
\hline \multirow{3}{*}{ 河道形状 $(\mathrm{m})$} & 低水路幅 & 6.0 \\
\cline { 2 - 3 } & 低水路水深 & 1.0 \\
\cline { 2 - 3 } & 高水敷幅 & 6.0 \\
\hline \multirow{2}{*}{ 法面勾配 } & 低水護岸 & $1 / 2$ \\
\cline { 2 - 3 } & 堤防法面 & $1 / 1$ \\
\hline
\end{tabular}

表-2 樹林条件

深 $h_{0}$ は低水路河床と水面との高低差と定義する.

\section{3. 解析事例の開水路諸元と水理条件}

\section{(1) 対象とする複断面開水路}

加古川の河口距離23.0 24.4km区間の諸元 ${ }^{23)}$ を参考に, 図-3のような複断面開水路の高水敷上全面に幅 $B_{\mathrm{v}}$ の樹林 帯を設定して2D2Lモデルによる等流解析を実施した. 低水路水深を $h_{\mathrm{M}}=1.0 \mathrm{~m}$ で一定とし, 低水路の満杯流量は 約 $10 \mathrm{~m}^{3} / \mathrm{s}$ である. 表-1に水理・河道条件，表-2に樹林条 件をそれぞれ示す。ここで，樹木密度 $N$, 密生度 $\lambda_{\text {veg }}$ は樹 径 $d$ ，樹木間隔 $\Delta S$ を用いて次式のように定義される.

$$
\lambda_{\text {veg }}=d h_{\mathrm{v}} / \Delta S^{2} h_{\mathrm{v}}=d / \Delta S^{2}=d \times N
$$

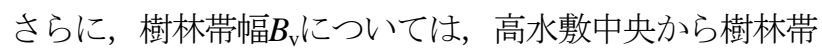
左右方向に等しく増減させた.

\section{4. マニングの相当粗度係数 $n_{v}$ の解析}

\section{(1) 流速分布の特性}

等流の達成状況を確認するため, 図-4にCASE- $1 \mathrm{~b} の Q$ $=150 \mathrm{~m}^{3} / \mathrm{s}$ における水深平均流速の平面分布の例を示寸. 等流状態の他，低水路一高水敷間の速度せん断構造など が確認される. 


\section{(2) 樹林が「水深-流量」, $" h_{0}-Q_{0}$ ”関係に及ぼす影響}

図-5に樹木条件 $\left[d, h_{\mathrm{v}}, B_{\mathrm{v}}, N\right]$ に対寸る $\left(h_{0}, Q_{0}, n_{\mathrm{v}}\right)$ の関係を 示す. 各曲線の白丸は，各CASEにおいて樹木が完全に 水没・冠水する水深 $\left(h_{0}=h_{\mathrm{v}}+h_{\mathrm{M}}\right)$ に対応する. この時の流 量を $Q_{\mathrm{M}}$ と定義する．いずれの図においても樹木冠水前 $\left(h_{0}<h_{\mathrm{v}}+h_{\mathrm{M}}\right)$ に比べて, 冠水後 $\left(h_{0} \geq h_{\mathrm{v}}+h_{\mathrm{M}}\right)$ の $Q_{0}$ に対する $h_{0}$ の 増加率が減少する. 寸なわち, $h_{0}$ とともに河積に占める 樹林面積の比率が相対的に減少するために, 樹木の疎通 能力低減効果が鈍り， $Q_{0}$ に対する $h_{0}$ の増加はやや線形的 になる.

\section{(a) $h_{0}$ vs. $Q_{0}$}

図-5(a)では $\left[h_{v}, B_{v}, N\right]$ が一定に設定されている. 樹径 $d$ が大きいほど $Q_{\mathrm{M}}$ は小さく, 疎通能力に及ぼす $d$ の影響, 間接的には $\lambda_{\text {veg }}$ の影響が反映されている。図-5(b)は， $[d$, $\left.B_{v}, N\right]$ が同一条件の下での樹高 $h_{\mathrm{v}}$ の影響を示している. 樹木冠水前 $\left(h_{0}<h_{\mathrm{v}}+h_{\mathrm{M}}\right)$ では全CASEが同じ $\left(h_{0}, Q_{0}\right)$ 関係をた ぞり， $h_{\mathrm{v}}$ が小さいCASEから順に樹木が冠水し始める $\left(h_{0} \geq h_{v}+h_{\mathrm{M}}\right)$. 冠水後, $h_{\mathrm{v}}$ が大きいCASEほど $h_{0}$ は大きく疎
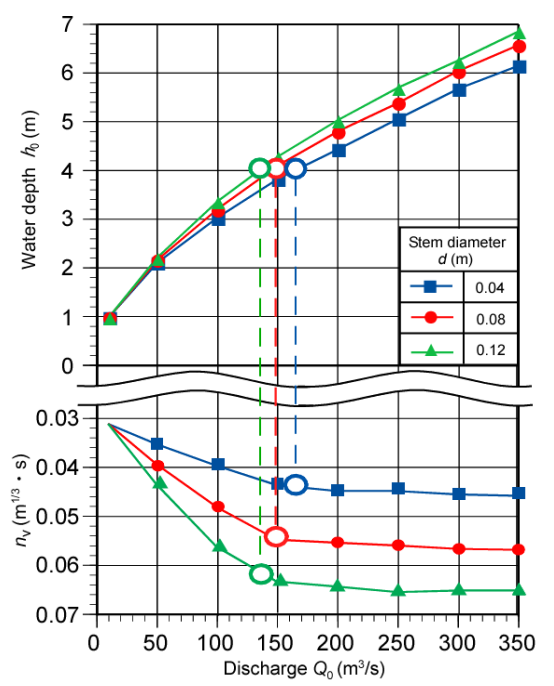

(a) 樹径 $に$ にる変化
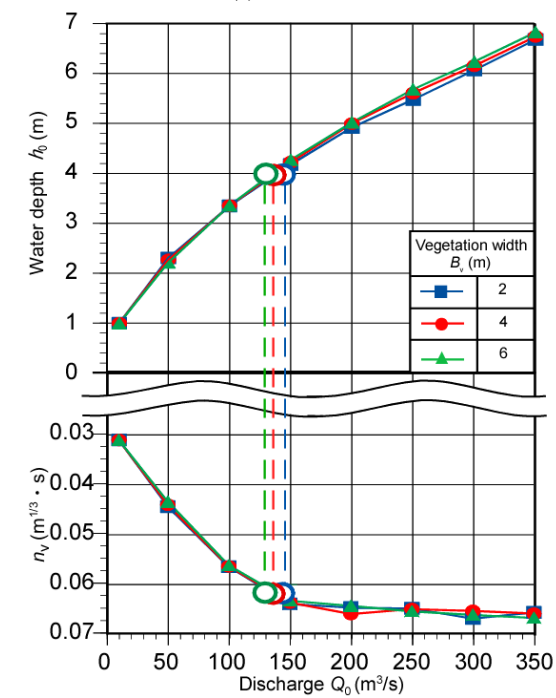

(c) 樹林帯幅 $B_{v}$ による変化
通能力は小さいことがあらわされている. 図-5(c)では, $\left[d, h_{v}, N\right]$ 一゙一定の下で樹林帯幅 $B_{\mathrm{v}}$ の疎通能力に及ぼす影 響を照査している， $B_{\mathrm{v}}$ の増加とともに等流水深 $h_{0}$ が大き くなり，疎通能力が減少することがわかる， $B_{\mathrm{v}}$ をより広 範に変化させれば，この傾向はより明確に現れる.

図-5(d)は， $\left[d, h_{\mathrm{v}}, B_{\mathrm{v}}\right]$ が一定で樹木密度 $N$ が変化した場合 の $\left(h_{0}, Q_{0}\right)$ 関係を示す. $N$ が疎通能力に及ぼす影響は顕著 に見られる.

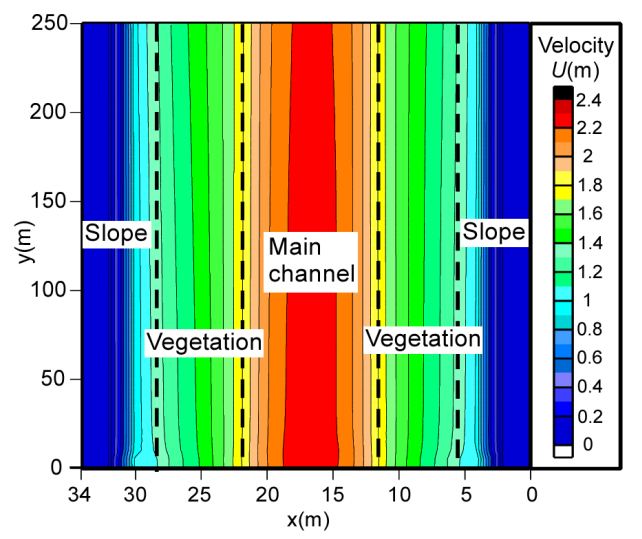

図-4 水深平均流速の平面分布

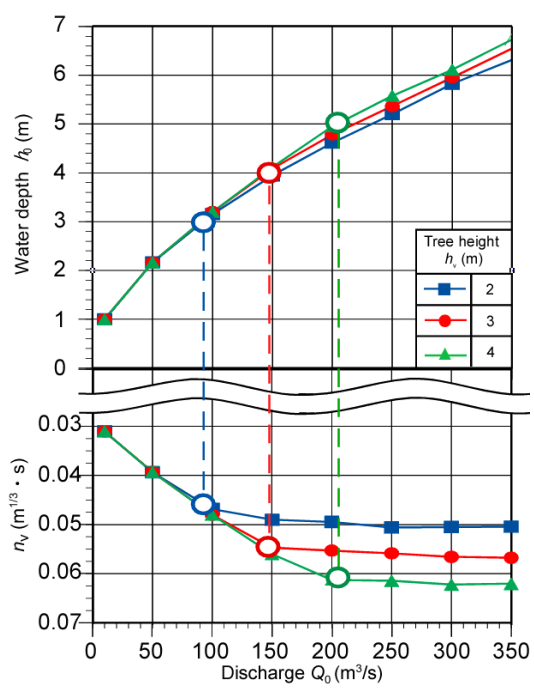

(b) 樹高 $h_{v}$ にる変化
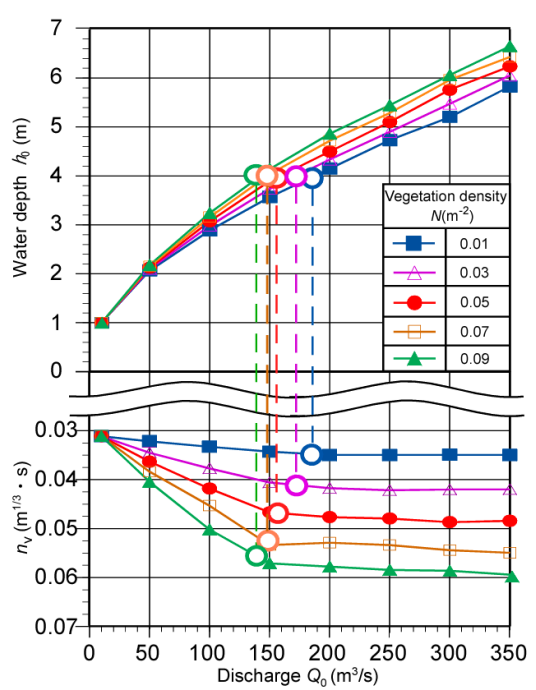

(d) 樹木密度 $N$ による変化 


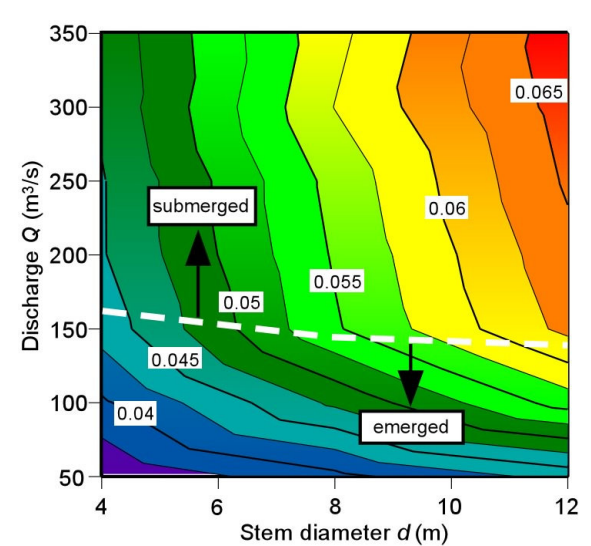

(a) 樹径 $d$ にる変化

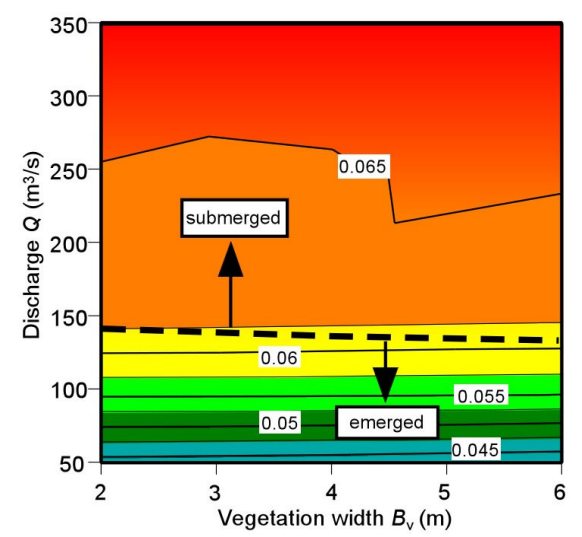

(c) 樹林帯幅 $B_{v}$ による変化

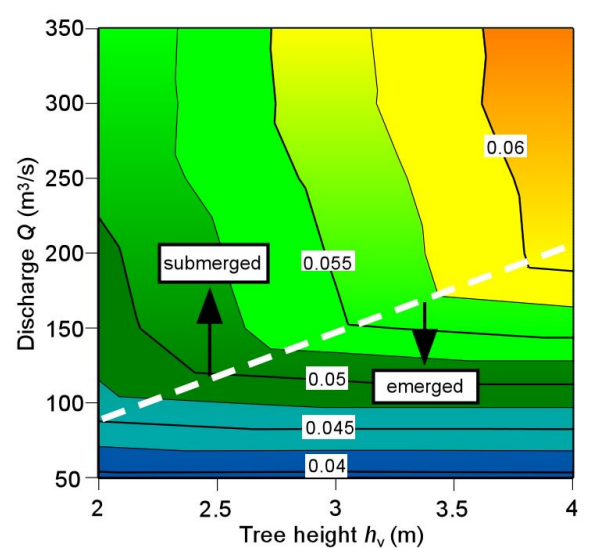

(b) 樹高 $h_{v}$ による変化

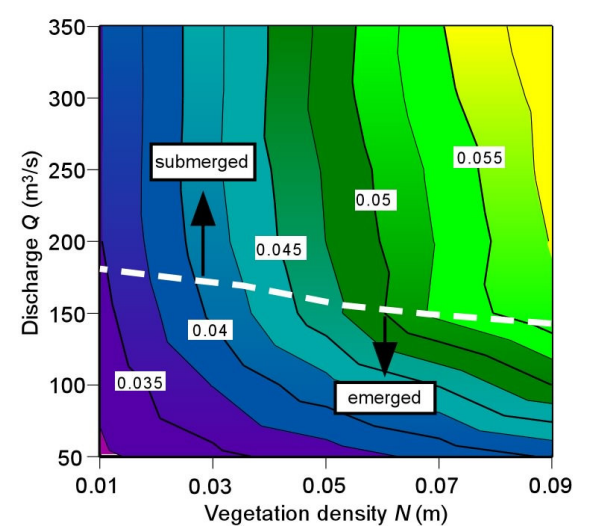

(d) 樹木密度 $N$ による変化

図-6 樹林帯領域の相当粗度係数

(b) $n_{\mathrm{v}}$ vs. $Q_{0}$

各パラメータ変化に応じた $\left(n_{v}, Q_{0}\right)$ の関係に着目する と，いずれのCASEにおいても樹林抵抗に応じて，相当 粗度係数が, $n_{\mathrm{v}}=0.03 \sim 0.07 \mathrm{~m}^{-1 / 3} \mathrm{~s}$ 範囲で変化している $\left(n_{\mathrm{v}}=n_{0}=0.03 \mathrm{~m}^{-1 / 3} \mathrm{~s}\right.$ : 林床の粗度係数 $)$. これより, 高水 敷樹林帯に対して慣例的に用いられるマニングの粗度係 数の範囲 $\left.\left(0.03 \sim 0.20 \mathrm{~m}^{-1 / 3} \mathrm{~s}\right)^{6}\right)$ と概社対応した相当粗度係数 $n_{\mathrm{v}}$ が得られていることが確認される.

樹木が冠水前の $\left(h_{0}<h_{\mathrm{v}}+h_{\mathrm{M}}\right.$, または, $\left.Q_{0}<Q_{\mathrm{M}}\right)$ におい ては， $n_{\mathrm{v}}$ が $Q_{0}$ とともに単調増加しているが，冠水後

$\left(h_{0} \geq h_{\mathrm{v}}+h_{\mathrm{M}}\right.$, または, $\left.Q_{0} \geq Q_{\mathrm{M}}\right)$ は， $\left(h_{0}, Q_{0}\right)$ に関係なく $n_{\mathrm{v}}$ がほぼ一定值をとることが特徵として見出される．この ことは通常の壁面粗度要素と同様に, $n_{v}$ が樹木条件 $\left[d, h_{v}\right.$, $\left.B_{v}, N\right]$ だけに依存する定数パラメータとして取り扱い可 能であることを示唆している. 特に, 高水計画の流量規 模を対象とする場合には樹林が冠水している状態がほと んどであり，このような $n_{v}$ 特性はHWL.の評価作業にお ける利点となる.

図-5(a) (d)の下図に示す $\left(n_{\mathrm{v}}, Q_{0}\right)$ を見れば，樹木抵抗に 関するパラメータの内 $\left[B_{\mathrm{v}}\right]$ の変化による $n_{\mathrm{v}}$ の顕著な変化 は確認されなかったが，その他の $\left[d, h_{v}, N\right]$ のずれが増 加しても $n_{\mathrm{v}}$ が増加する傾向が示されている. 今回の解析 条件は限定されており, しかも高水敷の粗度係数を大き く設定（ $n=0.055 ）$ したため， $B_{\mathrm{v}}$ の減少が $n_{\mathrm{v}}$ にぼす影響 が小さく表れたと考えられる.
(3) $n_{v}$ におよぼす $\left[d, h_{v}, B, N\right]$ 影響

$n_{\mathrm{v}}$ を $Q_{0}$ と $\left[d, h_{\mathrm{v}}, B_{\mathrm{v}}, N\right]$ の平面上に表記すれば図-6(a) (d) のようになる. 特に, 冠水後の流量規模に着目寸れば, $n_{\mathrm{v}}$ が樹木諸量 $\left[d, h_{\mathrm{v}}, N\right]$ とともに増加する傾向が図-5より も明確に確認される. なお, 図-6(c)を見ると, 本解析条 件の範囲では， $B_{\mathrm{v}}$ にともなう $n_{\mathrm{v}}$ の変化はほとんど見られ ない. 以上のように, 治水上重要となるような樹木が冠 水する規模の流量を対象として, より広範な樹林条件の 下で2D2Lモデル解析を実施すれば， $n_{\mathrm{v}}=$ Func. $\left[d, h_{v}, B_{\mathrm{v}}, N\right]$ の関係を定量的に見出すことが可能となる. その結果, たとえ洪水痕跡情報がない区間においても $n_{v}$ を水理学的 に評価することができ, 治水管理に必要な水面形を解析 することができる.

\section{5. 水理実験による本解析の検証}

\section{(1) 実験の概要}

$2 \mathrm{D} 2 \mathrm{~L}$ 等流解析から得られる相当粗度係数 $n_{\mathrm{v}}$ の妥当 性を検証するために水理模型実験を実施した。幅 $B=1.0 \mathrm{~m}$, 区間長 $L=8.0 \mathrm{~m}$ の単断面開水路の水路床勾配を $I=1 / 1,000$ に固定し, 表-3のような二つのCASEの諸元で 樹木模型（木製円柱）を水路床全面（ $B_{\mathrm{v}}=1.0 \mathrm{~m} ）$ に設置 した. 流量は $Q_{0}=1.87 \sim 27.157 / \mathrm{s} の$ 範囲で変化させ, 等流条 件を達成した後, 樹木部以外の潤辺粗度と等流水深・河 
床勾配などから，樹木部の相当粗度係数 $n$ 、を逆算した。 本実験は模型樹木の相当粗度係数 $n_{\mathrm{v}}$ の算定を目的として いるため, 図-3のような複断面開水路で実施する必要は なく単断面開水路を使用した。

\section{（2）本解析と水理実験との比較}

表-3の樹木条件に対して2D2Lモデル解析を実施し, 等流水深 $h_{0}$ と相当粗度係数 $n_{\mathrm{v}}$ を求めた. 前述のように, 2D2Lモデルは実河川・模型開水路のいずれにも適用実 績があり，任意断面形の開水路に適用可能である. 図-7 は $\left(h_{0}, Q_{0}\right)$ 関係を, 図-8は $\left(n_{v}, Q_{0}\right)$ 関係をそれぞれ示寸. 図 中の実線は，それぞれのCASEに対する2D2Lモデルの数 值解を示している. $n_{v}$ の実験值に見られるやや不規則な 傾向や解析值との偏差に関しては，水深・流量計測や等 流達成度に起因する誤差が関与していると考えられる. しかしながら，樹木冠水前後における疎通能力の変化や 密生度 $\lambda_{\text {veg }}$ が $\left(n_{v}, Q_{0}\right)$ 関係や相当粗度係数 $n_{\mathrm{v}}$ に及ぼす影響 など，実験值の傾向を本解析結果は概衩再現している. 以上のことから，2D2Lモデル解析に基づく前節までの 議論が妥当であることが実験的にも検証された.

\section{6. 結論}

国内外で樹林化が進行する河川の状況を鑑みると，樹 木植生が河川の疎通能力に及ぼ寸影響を的確に評価し， 治水計画に反映できるような樹木抵抗則を確立すること が急がれる. 治水計画に供することを目指して, 樹木の 流水抵抗をあらわす壁面粗度パラメータとしてのマニン グ相当粗度係数 $n_{\mathrm{v}}$ を二次元二層流（2D2L）モデルに基 づいて水理学的に評価した. その結果,

i) 樹木が水没し完全に冠水した水理条件下では, 流量・ 水位に関係なく粗度係数を一定として取り扱うことが できる.

ii) 樹木が冠水した場合には, $n_{\mathrm{v}}$ が樹木諸元 [樹高 $h_{\mathrm{v}}$, 樹

径 $d_{\mathrm{v}}$, 樹林幅: $B_{\mathrm{v}}$ 樹木密度 $\left.N\right]$ だけに依存する.

などの重要な知見を得ることができた，さらに，実験に より実現象でもこの傾向を確認することができた.

今後, $n_{\mathrm{v}}$ がマニングの粗度係数と同様に, 粗度要素条 件によって一意的に決定される定数か娝かを確認寸る必 要がある。広範な樹木条件に2D2Lモデルを適用し $n_{\mathrm{v}}=$ Func. $\left[d, h_{\mathrm{v}}, B_{\mathrm{v}}, N\right]$ の関数関係を確立すること，実河川 を含むより一般的な河道地形，樹林分布，水理条件に対 して $n_{\mathrm{v}}$ を求め, 本研究成果の普遍性を検証することが課 題と考えている.

謝辞 : 本研究に際しては，国土交通省姫路河川国道事務 所関係各位のご協力を頂いた。.また，平成23-25年(2013) 度科学研究費基盤研究(B) (代表 : 道奥康治, 課題番 号 : 23360212）の助成の下で実施された. 以上，記して
表-3 実験条件

\begin{tabular}{|c|c|c|c|c|c|}
\hline CASE & $\begin{array}{l}\text { 樹径 } \\
d(\mathrm{~cm})\end{array}$ & $\begin{array}{c}\text { 樹高 } \\
h_{\mathrm{V}}(\mathrm{cm}) \\
\end{array}$ & $\begin{array}{c}\text { 樹木間隔 } \\
\Delta S(\mathrm{~cm}) \\
\end{array}$ & $\begin{array}{l}\text { 樹木密度 } \\
N\left(\text { 本 } / \mathrm{cm}^{2}\right)\end{array}$ & $\begin{array}{l}\begin{array}{c}\text { 密生度 } \\
\lambda_{\text {veg }}\left(\mathrm{cm}^{-1}\right)\end{array} \\
\end{array}$ \\
\hline 1 & \multirow{2}{*}{0.6} & \multirow{2}{*}{6.0} & 21.9 & 0.00208 & 0.00125 \\
\hline 2 & & & 10.95 & 0.00834 & 0.005 \\
\hline
\end{tabular}

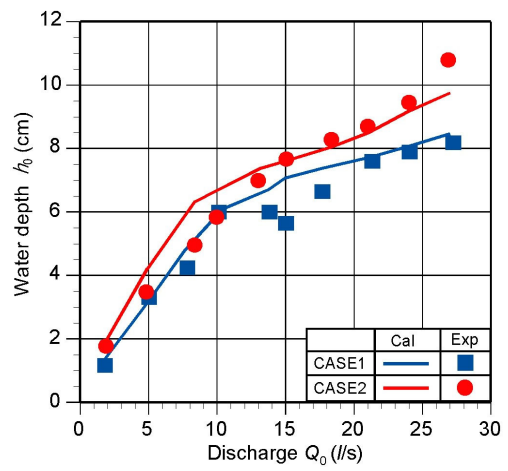

図-7 $\left(h_{0}, Q_{0}\right)$ に関する本解析と水理実験との比較

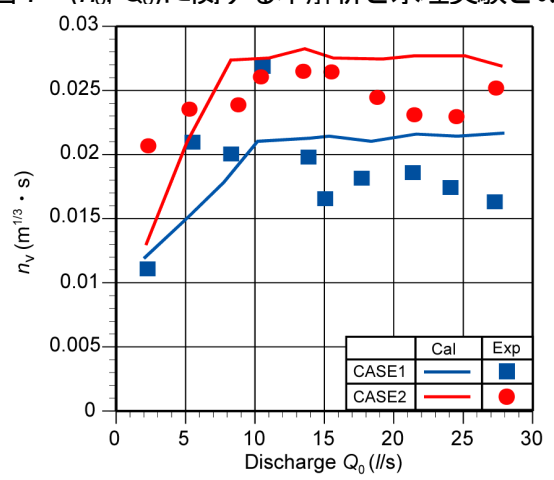

図-8 $\left(n_{v}, Q_{0}\right)$ l関する本解析と水理実験との比較

謝意を表する.

\section{参考文献 :}

1) 道奥康治・南條雅志・石垣泰輔・前野詩朗 : 捨石水制が冠水 した開水路流の二次元二層流モデル, 土木学会論文集, No.782/II-70, pp.31-50, 2005.

2) 道奥康治・宮本仁志・神田佳一 ・大地洋平・阿賀一穂 ・ 盛岡 淳二・魚谷拓矢・吉田一亮・吉村敏 : 樹林化した河道の流況 観測之樹林内外の流況・樹木抗力の解析，河川技術論文集， 第16巻, pp. 437-442, 2010.

3) 道奥康治・宮本仁志・神田佳一 ・地洋平 : 樹林汃繁茂した 加古川中流部における出水時流況之樹林損壊に関寸る調查 解析, 土木学会論文集B1 (水工学), 第55巻, pp.S_1087S_1092, 2011.

4) K. Michioku, et al.: Hydrodynamics and hydromorphology of river structures constructed by natural materials, Proc. 6th Intnl. Conf. Water Resources and Environment Research, Water \& Environment Dynamics, 2013.

5) M. Taniguchi, K. Aga, K. Michioku and K.Kanda: Hydrodynamic influence of vegetated floodplain morphology on drag force moment acting on trees, Proc. 35th IAHR World Congress, 2013.

6) 水理委員会編 : 水理公式集, pp.89, 1990. 